ECONOMICS

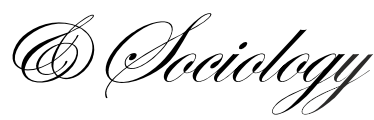

\author{
Edvīns Šincāns, \\ Dangaupils University, \\ Daugaupils, Latvia, \\ E-mail: \\ Edvins.Sincans@latvenergo.lv
}

Svetlana Ignatjeva,

Daugavpils University,

Daugaupils, Latvia,

E-mail:Svetlana.ignatjeva@du.lv

\author{
Manuela Tvaronavičienė, \\ Vilnius Gediminas Technical \\ University, \\ The General Jonas Žemaitis \\ Military Academy of Lithuania, \\ Vilnius, Lithuania, \\ E-mail: \\ manuela.tvaronaviciene@vgtu.lt
}

Received: June, 2016

1st Revision: October, 2016

Accepted: November, 2016

DOI: $10.14254 / 2071-$

789X.2016/9-4/20
Šincāns, E., Ignatjeva, S., Tvaronavičienė, M. (2016), Issues of Latvian Energy Supply Security: Evaluation of Criminal Offences in Latvia's Electricity Market, Economics and Sociology, Vol. 9, No 4, pp. 322-335. DOI: 10.14254/2071-

789X.2016/9-4/20

\section{ISSUES OF LATVIAN ENERGY SUPPLY SECURITY: EVALUATION OF CRIMINAL OFFENCES IN LATVIA'S ELECTRICITY MARKET}

\begin{abstract}
Recognized criminal offences in the field of electrical power engineering services do harm to energy supply merchants, users of electric energy, and human lives and health, and leave a negative effect on economic development. According to Directive 2009/72/EC of the European Parliament and of the Council of 13th July 2009 concerning common rules for the internal market in electricity and repealing Directive 2003/54/EC cancellation requirements, doing historically important electric energy market opening process, it is important to promote more effective measures for the prevention of security threats and criminal offences to energy supply objects.

Latvian energy supply security is one of the key areas of energy policies implementation for the next seven years. Led by this aim, the Ministry of Economics has developed energy development guidelines for the period of 20162020 (2016), giving suggestions to Latvian government's basic political principles, aims, and action directions in energy for the next five years. The Cabinet of Ministers has confirmed the guidelines. In order to successfully carry out the abovementioned basic principles, it is necessary to strengthen the prevention of threats to energy supply security, and the specifics of counteraction should be examined within the framework of prevention and combating of crimes, in order to contribute to economic development.

The present research sought to obtain specialists' opinions about criminal offences, specifics of such offences, and possible solutions. The research was conducted in 2015, when Latvia achieved historically significant electric energy market opening process. The analysis of the results of the questionnaire and statistical data concluded that successful combating of criminal offences in electric energy market primarily depends on police resources, energy supply, merchant's technical solutions, and specialists' cooperation.
\end{abstract}

JEL Classification: Q41, Q48

Keywords: energy security, electric energy market, criminal offences, Latvia. 


\section{Introduction}

There are a lot of factors that influence the efficiency of efforts preventing criminal offences of an economic nature; these factors include networking of stakeholders (e.g., Akhmadeev and Manakhov, 2015; Ala-Juusela et al., 2014; Aleksejeva, 2016; Barberis et al., 2014; Branten and Purju, 2015; Čirjevskis, 2015; Cuneo et al., 2014; Fuschi and Tvaronavičienè, 2016) and level of development of country (e.g., Corneliu, Tamošiūnienè, 2015; Balitskiy et al., 2014; Balkyte and Tvaronavičiene, 2010; Dudzevičiūtè et al., 2014; Lapinskienè et al., 2013; Lapinskienè et al., 2014; Białowąs, 2015; Pires Manso et al., 2015; Balitskiy et al., 2016). The list of factors could continue much further, but suffice it to summarize that they are often categorized into "soft," or indirect, factors, and "hard" factors, together encompassing all mechanisms of enforcement, from legislation to punishment of crimes. Taking into account the complexity of the phenomenon itself, we want to delineate the context of our research.

The energy security of a country involves a number of different facets, such as energy availability, efficiency, and afordability (Cherp and Jewell, 2014; Dezellus et al., 2015; Lisin et al., 2015; Espona, 2016); level of techology novelty and its vulnerability (Grubicka and Matuska, 2015; Prause, 2016); public sector performance (Bileišis, 2014; Borshchevska, 2015; Caurkubule, Rubanovskis, 2014; Garškaitè-Milvydienè, 2014; Laužikas et al., 2015); and available means to enhance social security (Bilevičienè and Bilevičiūtè, 2015; Bistrova et al., 2014; Dzemyda and Raudeliūnienè, 2014; Tvaronavičienè et al., 2015). In addition to these, behavioral patterns also undeniably affect a country's energy security.

To determine the significance of criminal offences in electric power engineering services in Latvia and to evaluate the efficiency of solutions therefor, the authors of this research developed a questionnaire targeting specialists from various sectors in Latvia: law enforcement institutions (police and prosecutor's office) and employees of energy companies (JSC "Latvenergo", JSC "Sadales tīkls"). These specialists represent the population of the empirical research. The questionnaire was conducted electronically (http://aptaujas.du.lv/index.php/813329/lang-lv), and the responses served as the data for this empirical research.

Research hypotheses were formulated taking into account various factors that influence criminal offence in electric power engineering services: fraud icentives (Girūnas and Mackevičius, 2014; Giriūnienè, 2013; Išoraite, 2013; Lace et al., 2015; Laužikas and Mokšeckienė, 2013); technology (Gerlitz, 2016; Guruz and Scherer, 2014; Ignatavičius et al., 2015; Jefremov and Rubanovskis, 2015; Iganatavičius et al., 2015; Grubicka and Matuska, 2015; Rezk et al., 2015; Prause, 2016); perceptions of energy security (Miškinis et al., 2013; Månsson et al., 2014; Raudeliūnienè et al., 2014; Leonavičius et al., 2015; Narula and Reddy, 2015; Njaramba et al., 2015; Oganisjana and Surikova, 2015); and risk awareness (Ruza et al., 2016). Authors put particular emphasis on enforcement efficiency. Therefore, the following hypotheses were formulated:

- Protection of electric energy market through criminal law is important and topical both for energy supply companies and police officers.

- There is a necessity for legislative framework modernization in order to prevent criminal offences in the electric energy market.

- An appropriate provision of police resources is necessary to prevent criminal offences in the electric energy market and to ensure effective protection of the said market.

- There are differences in the evaluation of the efficiency of various groups of measures used to resolve criminal offences in the electric energy market. 
- There is interdependence between the evaluation of the problem of illegal usage of electric energy and the effective application of various groups of measures to solve the problem.

The questionnaire was sent to 421 respondents, of which 317 specialists responded within the period between November 24, 2015, and December 15, 2015. Of the respondents, $112(35,3 \%)$ were specialists from law enforcement institutions, and $205(64,7 \%)$ were employees of energy companies. All of their responses were included as data for the research. The respondents represented all regions of Latvia, and the sample was stratified. The sample is representative in relation to the population (Yadov, 2007).

The age of law enforcement specialists who participated in the research varied from 18 to 59 years, with an average age of 36,5. Their average length of service was 15 years. The age of employees of energy supply companies varied from 24 to 74 years, with an average age of 44 years. Their average length of service was 19 years.

The software package IBM SPSS Statistics 23 for Windows was used for the statistical analysis of data and presentation of the research (Nasledov, 2005; Byuyul, Tsyofel, 2005; Kryishtanovskiy, 2006).

Data analysis during the research consisted of adaptation of the questionnaire and intelligence analysis, which enabled the researchers to test the hypotheses.

P-level (level of statistical significance) equal to 0.05 is considered a permissible error for the results observed in the whole population. If $0.05<p<0.1$, it is considered a statically significant dependence.

The questionnaire contained 41 questions to obtain as much information as possible to form a full picture of the respondents' opinions and to allow for the analysis of:

- the significance of the problem of criminal offences in the electric energy market; and

- the efficiency of various groups of measures to solve the problem of criminal offences in electric energy market.

\section{Analysis of the significance of criminal offences in electric energy market}

In order to analyse the factor structure of the questionnaire, the researchers conducted an exploratory factor analysis of both its parts. The Kaiser-Meyer criterion of sampling adequacy for the first part of the questionnaire was 0,798 , which indicates purposefulness of the use of factor analysis for the analysis of the structure of vision of the problem of criminal offences in the electric energy market.

Factor analysis determined a five-factor structure of the research problem, reflect these factors:

F1 - the level of significance and topicality of the problem.

$\mathrm{F} 2$ - the level of resource provision.

F3 - the level of judicial competence of the society.

F4 - the level of the impact of objective factors on the problem.

F5 - the level of society awareness about the danger caused by the problem.

Table 1 summarizes the factor loadings of these indicators, which determine the semantics of the distinguished factors. The first of the distinguished factors (F1) explains showed a variance of 15\%; F2, 11,8\%; F3, 11,6\%; F4, 9,4\%; and F5, 9,2\%. The total variance rate of all distinguished factors was $57 \%$.

The values of Cronbach's alpha criterion, given in Table 1, are within the range of 0,806 to 0,907 , which indicates high enough coherence of separate questionnaire items. The indicators of the distinguished factors are derived as arithmetic means of corresponding indicators. 
INTERDISCIPLINARY APPROACH TO ECONOMICS AND SOCIOLOGY

Table 1. Factor structure and factor loadings of indicators which reflect the problem

\begin{tabular}{|c|c|c|c|c|c|c|}
\hline & & & & & & \\
\hline & & F1 & F2 & F3 & F4 & F5 \\
\hline \multirow{3}{*}{ F1 } & $\begin{array}{l}\text { Criminal offences significantly damage not only } \\
\text { energy supply merchants, but also public economy }\end{array}$ & ,785 & & & & \\
\hline & $\begin{array}{l}\text { Electric energy losses are significant and affect } \\
\text { attraction of energy supply merchant's resources for } \\
\text { other important energy supply problems }\end{array}$ & ,745 & & & & \\
\hline & $\begin{array}{l}\text { There is a necessity for legislative framework } \\
\text { modernization related to crimes and criminal offences } \\
\text { in electric energy market }\end{array}$ & 657 & & & & \\
\hline \multirow{3}{*}{$\mathrm{F} 2$} & $\begin{array}{l}\text { Energy supply personnel does not have serious } \\
\text { motivation to disclose criminal offences in electric } \\
\text { energy market and is not interested in accomplishing } \\
\text { effective tasks to improve the situation }\end{array}$ & & ,796 & & & \\
\hline & $\begin{array}{l}\text { There is no practical training for the personnel of } \\
\text { energy supply merchant on the analysis of criminal } \\
\text { offences and setting tactical goals }\end{array}$ & & ,781 & & & \\
\hline & $\begin{array}{l}\text { Investments of energy supply merchant into security } \\
\text { are insufficient }\end{array}$ & & ,748 & & & \\
\hline \multirow{4}{*}{ F3 } & $\begin{array}{l}\text { Illegal services are provided for population to create } \\
\text { unlicensed connections to electric energy }\end{array}$ & & & ,768 & & \\
\hline & $\begin{array}{l}\text { Population is more interested in providing help to } \\
\text { criminals, so that they would have an opportunity to } \\
\text { avoid liability, than to energy supply merchant }\end{array}$ & & & 695 & & \\
\hline & $\begin{array}{l}\text { Society is not aware of the seriousness of criminal } \\
\text { offences }\end{array}$ & & &, 561 & & \\
\hline & $\begin{array}{l}\text { Society has not enough public information about } \\
\text { criminal offences }\end{array}$ & & &, 543 & & \\
\hline \multirow{3}{*}{ F4 } & $\begin{array}{l}\text { The number of committed criminal offences is related } \\
\text { to tax policy }\end{array}$ & & & & ,808 & \\
\hline & $\begin{array}{l}\text { The number of committed criminal offences is related } \\
\text { to economic situation }\end{array}$ & & & &, 722 & \\
\hline & $\begin{array}{l}\text { Police officers are not particularly aware of the } \\
\text { seriousness of criminal offences in electric energy } \\
\text { market and do not have serious motivation to } \\
\text { accomplish effective tasks to improve the situation }\end{array}$ & & & & ,475 & \\
\hline \multirow{2}{*}{ F5 } & Criminal offences are dangerous to the society & & & & &, 816 \\
\hline & Energy supply security is important for the society & & & & &, 765 \\
\hline
\end{tabular}

Table 2. Descriptive statistics of factors which reflect the problem

\begin{tabular}{|c|c|c|c|c|c|c|}
\hline & & & & & \\
\hline & & F1 & F2 & F3 & $\mathrm{F} 4$ & F5 \\
\hline \multicolumn{2}{|l|}{ Arithmetic mean } & 4,21 & 3,01 & 2,51 & 3,72 & 4,42 \\
\hline \multicolumn{2}{|l|}{ Median } & 4,00 & 3,00 & 2,50 & 4,00 & 4,50 \\
\hline \multicolumn{2}{|l|}{ Mode } & 4,00 & 3,00 & 2,50 & 4,00 & 4,00 \\
\hline \multicolumn{2}{|l|}{ Standard deviation } & ,621 & ,724 & 509 & ,610 & 479 \\
\hline \multicolumn{2}{|l|}{ Range } & 3,67 & 4,00 & 3,00 & 3,33 & 3,50 \\
\hline \multicolumn{2}{|l|}{ Lowest sample variance } & 1,33 & 1,00 & 1,00 & 1,67 & 1,50 \\
\hline \multicolumn{2}{|l|}{ Highest sample variance } & 5,00 & 5,00 & 4,00 & 5,00 & 5,00 \\
\hline \multirow{3}{*}{ Percentiles } & 25 & 3,83 & 2,67 & 2,25 & 3,33 & 4,00 \\
\hline & 50 & 4,00 & 3,00 & 2,50 & 4,00 & 4,50 \\
\hline & 75 & 4,67 & 3,33 & 2,75 & 4,00 & 5,00 \\
\hline
\end{tabular}


According to the Kolmogorov-Smirnov criterion, the distribution of all the factors, which reflect the evaluation of the problem, differs significantly from normal.

Furthermore, respondents gave the highest rating to factor F5, which reflects the level of awareness of the society about the danger caused by the problem. The evaluation of this factor varied from 1,5 to 5 , but not fewer than half of respondents gave a rating higher than 4,5 . The lowest variation of the aforementioned factor was $(\sigma=0,479)$ and the highest average value was $(\mathrm{v}=4,42)$. The results of the questionnaire suggest that respondents understand and are aware of the danger of criminal offences in the electric energy market and the importance of energy supply security for the society.

The lowest rating was for factor F3 which reflects the level of judicial competence of the society. The evaluation of this factor varied within the range of 1 to 4 , but half of respondents gave a rating no more than 2,5 , and $25 \%$ of respondents' evaluation did not exceed 2,25. The lowest average value of this factor was $(\mathrm{v}=2,51)$.

The highest variation $(\sigma=0,724)$ was in factor F2, which reflects the level of resource provision. Half of respondents gave a rating not higher than 3. F2 has the highest amplitude of variations and it is equal to 4 (Table 2).

According to the Mann-Whitney criterion, the evaluation of all factors, except F3, has statistically significant differences among police officers and employees of energy supply companies. Factor F3 was evaluated equally low by all respondents. The average evaluation of this factor was 2,58 by police officers, but 2,47 by employees of energy supply companies. Moreover, representatives of police structures evaluated factors F2 and F5 lower than the average, but employees of energy supply companies rated them higher. On the other hand, police officers gave higher ratings to factors $\mathrm{F} 1$ and $\mathrm{F} 4$.

It was established that the aforementioned differences are regular, as specialists of law enforcement institutions evaluate higher the significance of damage and the relation of criminal offences to economic situations. They also believe that they do not have serious motivation to accomplish effective tasks to improve the situation. In contrast, employees of energy supply companies evaluate higher the danger caused by criminal offences, the importance of security, and the situation when energy supply personnel does not have serious motivation to disclose criminal offences and is not interested to accomplish effective tasks to improve the situation. However, in spite of these differences, the questionnaire results suggest that respondents' opinions do not differ significantly and that $92,8 \%$ of respondents are aware of the seriousness of the problem of criminal offences in the electric energy market and believe that it significantly damages not only energy supply merchants, but also public economy.
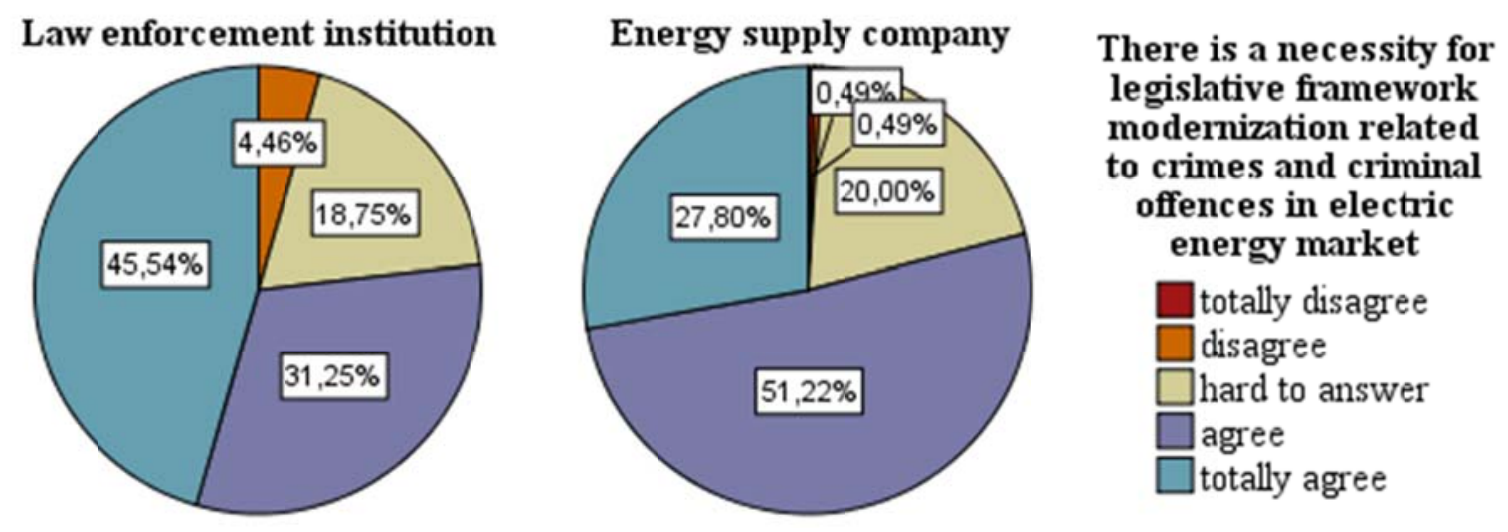

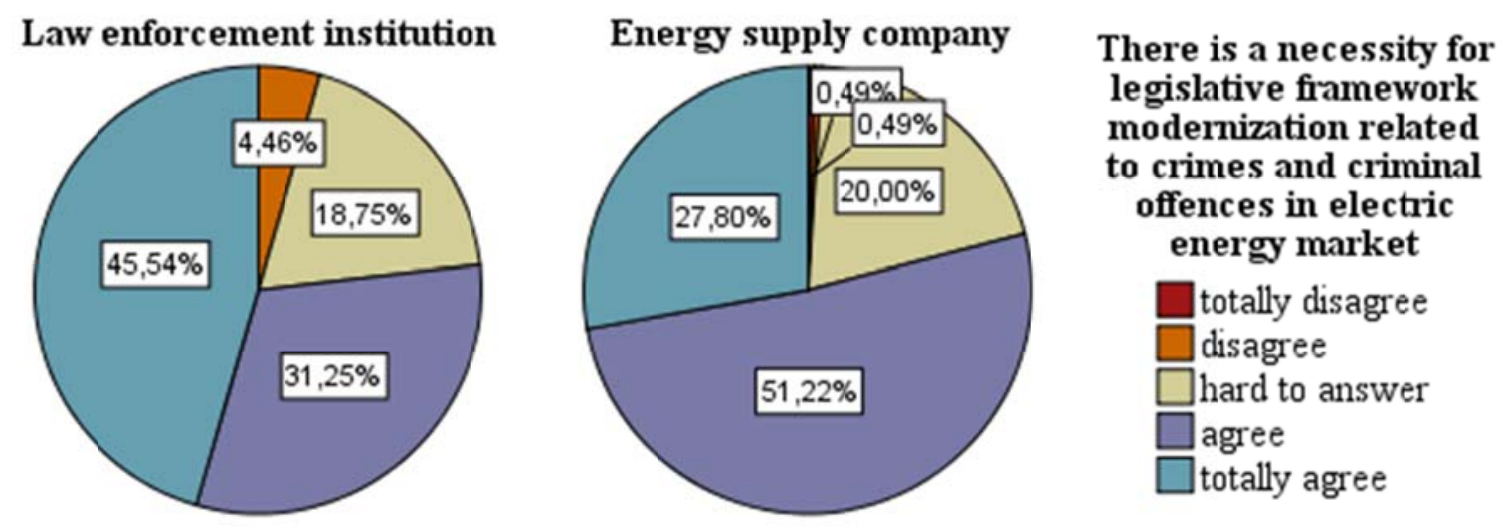

Figure 1. Distribution of answers on the necessity of modernisation of normative legislative framework among the representatives of police and energy supply companies

Source: own research.

The analysis of the answers on the necessity of modernisation of normative legislative framework shows that approximately $77 \%$ of police officers and $79 \%$ of energy supply specialists agreed or totally agreed that normative legislative framework should be modernized (Figure 1). This evaluation indicates that almost $80 \%$ of all respondents support the necessity of improving legislation related to crimes and criminal offences in the electric energy market.

\section{Analysis of the solutions for criminal offences in electric energy market}

Factor analysis of the indicators that reflect the measures to solve the problems of criminal offences allows the researchers to determine six homogeneous clusters (groups) among them:

E1 - the efficiency of public communication and importance of correct information.

E2 - the efficiency of cooperation and resource provision.

E3 - the efficiency of modern technical aids provision.

E4 - the efficiency of preventive measures and improvement of legislative framework.

E5 - the efficiency of management peculiarities and importance of security analysis.

E6 - the topicality of other possible propositions.

Table 3 presents the factor loadings of these indicators, which determined the semantics of the distinguished factors.

The first of the distinguished factors (E1) showed total variance of 17\%; factor E2, $12 \%$; E3, $11,7 \%$; E4, 8,3\%; E5, 7,8\%; and E6, 7,2\%. The total variance rate of all the distinguished factors was $64 \%$.

The values of Cronbach's alpha criterion, given in Table 5, were within the range of 0,786 to 0,930 , which indicates high enough coherence of separate questionnaire items. The indicators of the distinguished factors are derived as arithmetic means of corresponding indicators. 
Table 3. Factor structure and factor loadings of indicators which reflect the efficiency of measures to solve the problem

\begin{tabular}{|c|c|c|c|c|c|c|c|}
\hline & & E1 & E2 & E3 & E4 & E5 & E6 \\
\hline 1 & 2 & 3 & 4 & 5 & 6 & 7 & 8 \\
\hline \multirow{5}{*}{ E1 } & $\begin{array}{l}\text { Before testing clients' objects, it is necessary to } \\
\text { publish information in mass media on the complex } \\
\text { of measures taken to detect cases of illegal usage of } \\
\text { electric energy }\end{array}$ & ,779 & & & & & \\
\hline & $\begin{array}{l}\text { Municipalities must protect low-income persons and } \\
\text { provide them with remuneration for minimum } \\
\text { electric energy consumption }\end{array}$ & ,707 & & & & & \\
\hline & $\begin{array}{l}\text { Energy supply merchants should provide police with } \\
\text { the necessary information, correct data and } \\
\text { evidences to eliminate doubts }\end{array}$ & ,707 & & & & & \\
\hline & Police needs to be provided with additional resources & ,641 & & & & & \\
\hline & $\begin{array}{l}\text { Energy supply merchants should provide an } \\
\text { opportunity for citizens to inform electric energy } \\
\text { system operators via special telephone numbers } \\
\text { about suspicious cases of possible crimes in electric } \\
\text { energy networks }\end{array}$ & ,627 & & & & & \\
\hline \multirow{4}{*}{ E2 } & $\begin{array}{l}\text { The personnel of energy supply merchants should go } \\
\text { through not only theoretical, but also practical } \\
\text { training. It is necessary to analyse criminal offences, } \\
\text { set tactical goals, control the application of } \\
\text { knowledge in practice, and to carry out certification }\end{array}$ & & ,717 & & & & \\
\hline & $\begin{array}{l}\text { Energy supply merchant should motivate its } \\
\text { employees involved in the detection of criminal } \\
\text { offences, by linking wages to individual work results }\end{array}$ & & ,698 & & & & \\
\hline & $\begin{array}{l}\text { The security service of energy supply merchant and } \\
\text { police should develop closer cooperation in } \\
\text { detection and prevention of criminal offences in } \\
\text { electric energy market, in case of need agree upon } \\
\text { the necessary provisioning (equipment, fuel, etc.) }\end{array}$ & & ,628 & & & & \\
\hline & $\begin{array}{l}\text { Police officers should undergo professional training } \\
\text { and courses }\end{array}$ & &, 593 & & & & \\
\hline \multirow{3}{*}{ E3 } & $\begin{array}{l}\text { It is essential for energy supply merchant to install } \\
\text { control measurement devices at transport and } \\
\text { distribution points }\end{array}$ & & & ,832 & & & \\
\hline & $\begin{array}{l}\text { Energy supply merchant should transfer measuring } \\
\text { devices out of client's territory }\end{array}$ & & & ,767 & & & \\
\hline & $\begin{array}{l}\text { Energy supply merchant should continue the } \\
\text { program on replacement of current meters with } \\
\text { smart meters that are able to provide information on } \\
\text { the actual electric energy consumption }\end{array}$ & & & ,723 & & & \\
\hline \multirow[b]{3}{*}{ E4 } & $\begin{array}{l}\text { Regular unauthorized connections to electric lines } \\
\text { by offenders should be criminalized }\end{array}$ & & & &, 841 & & \\
\hline & $\begin{array}{l}\text { It might be effective, if a criminal liability warning } \\
\text { would follow administrative punishment for illegal } \\
\text { usage of electric energy }\end{array}$ &, 553 & & &, 588 & & \\
\hline & $\begin{array}{l}\text { Publications of preventive character on danger } \\
\text { caused by criminal offences should be published in } \\
\text { mass media, which would describe the consequences } \\
\text { and liability, thus promote informative and } \\
\text { instructive work with the society and increase the } \\
\text { awareness of population about their rights }\end{array}$ & ,437 & & &, 531 & & \\
\hline
\end{tabular}


INTERDISCIPLINARY APPROACH TO ECONOMICS AND SOCIOLOGY

\begin{tabular}{|c|c|c|c|c|c|c|}
\hline 1 & 2 & 4 & 5 & 6 & 7 & 8 \\
\hline \multirow[b]{2}{*}{ E5 } & $\begin{array}{l}\text { Energy supply merchants should continue } \\
\text { reconstruction of overhead lines into cable lines }\end{array}$ & & & &, 765 & \\
\hline & $\begin{array}{l}\text { Energy supply merchant should dismantle networks at } \\
\text { objects where services are no longer provided (disused } \\
\text { objects), thus preventing offenders from stealing } \\
\text { electric energy and cables }\end{array}$ & & & & ,630 & \\
\hline \multirow{3}{*}{ E6 } & $\begin{array}{l}\text { The number of criminal offences has increased within } \\
\text { the last } 5 \text { years }\end{array}$ & & & & & ,752 \\
\hline & $\begin{array}{l}\text { Those places where criminal offences are committed } \\
\text { regularly should be included in police inspection } \\
\text { routes }\end{array}$ & ,479 & & & &, 597 \\
\hline & Energy supply merchants should recruit detectives & & & & &, 550 \\
\hline
\end{tabular}

Source: own research.

Table 4. Descriptive statistics of factors which reflect the efficiency of various groups of measures used to solve the problem

\begin{tabular}{|c|c|c|c|c|c|c|}
\hline & E1 & E2 & E3 & $\mathrm{E} 4$ & E5 & E6 \\
\hline Arithmetic mean & 4,00 & 3,98 & 4,34 & 4,05 & 3,96 & 3,34 \\
\hline Median & 4,00 & 4,00 & 4,67 & 4,33 & 4,00 & 3,33 \\
\hline Mode & 5,00 & 4,00 & 5,00 & 4,33 & 4,00 & 3,00 \\
\hline Standard deviation & ,742 & ,511 & ,708 & ,584 &, 574 & ,616 \\
\hline Range & 4,00 & 3,25 & 4,00 & 4,00 & 3,33 & 3,33 \\
\hline Lowest sample variance & 1,00 & 1,75 & 1,00 & 1,00 & 1,67 & 1,67 \\
\hline Highest sample variance & 5,00 & 5,00 & 5,00 & 5,00 & 5,00 & 5,00 \\
\hline 25 & 3,40 & 3,75 & 4,00 & 3,67 & 3,67 & 3,00 \\
\hline Percentiles & 4,00 & 4,00 & 4,67 & 4,33 & 4,00 & 3,33 \\
\hline 75 & 4,60 & 4,25 & 5,00 & 4,33 & 4,33 & 3,67 \\
\hline
\end{tabular}

Source: own research.

According to the Kolmogorov-Smirnov criterion, the distribution of all the factors that reflect the evaluation of the problem differs significantly from normal.

Respondents gave the highest rating to factor E3 (the efficiency of modern technical aids provision). Half of respondents gave a rating not lower than 4,67 , but no fewer than $25 \%$ of respondents believed that these measures are effective. The lowest evaluation was given to factor E6 (the topicality of other possible propositions). Half of respondents gave a rating lower than 3,33. The highest dispersion of values was observed for factor E1 (the efficiency of public communication and importance of correct information). Half of respondents gave a rating not lower than $4,25 \%$ - higher than 4,6 , but $25 \%$ of respondents gave a rating not to exceed 3,4 (Table 4).

Factor E1 (the efficiency of public communication and importance of correct information) was evaluated by police officers to be higher than on average, whereas employees of energy supply companies evaluated this factor as lower than on average. At least half of police officers evaluated this factor not lower than 4,8, whereas employees of energy supply companies generally rated this at 3,8 or above.

It should be noted that among factor E1 indicators, respondents gave greatest support to the statement that energy supply merchants should provide police with the necessary information, correct data, and evidences to eliminate doubts, a statement positively evaluated 
by $87 \%$ of respondents. On the other hand, $82,7 \%$ of respondents believe that police needs to be provided with additional resources.

Among E2 factor (the efficiency of cooperation and resource provision) indicators, respondents gave greatest support to the statement that energy supply merchants should motivate their employees who are involved in the detection of criminal offences, with $86,8 \%$ of all respondents indicating support. On the other hand, $84,5 \%$ of respondents believed that the security service of energy supply merchants and police should develop closer cooperation in detection and prevention of criminal offences in the electric energy market, in case of need agree upon the necessary provisioning (equipment, fuel, etc.).

Factor E3 (the efficiency of modern technical aids provision) is evaluated higher by the police officers, with at least half of them giving it highest evaluation; however, $75 \%$ of employees of energy supply companies evaluated this factor to be not lower than 4 . At the same time, $87 \%$ of respondents agreed that energy supply merchant should transfer measuring devices out of clients' territory and continue the program on replacement of current meters with smart meters that are able to provide information on the actual electric energy consumption. Positive evaluation indicates that respondents believed it is necessary for the energy supply merchant to constantly improve the effective application of technical aids according to present-day requirements.

According to the Mann-Whitney criterion, the evaluation of factors E1, E3, E4, E6 has statistically significant differences among police officers and employees of energy supply companies. Factors E2 and E5 are evaluated equally by all respondents.

The analysis of the answers concerning the necessity to criminalize regular unauthorized connections to electric lines given in the factor E4 (the efficiency of preventive measures and improvement of legislative framework) shows that approximately $67 \%$ of police officers and $40 \%$ of employees of energy supply companies believed that criminal liability is a very effective method. $21 \%$ of police officers and $48 \%$ of employees of energy supply companies evaluate the aforementioned measure as effective. Such evaluation suggests that respondents believe criminal liability should be applied for illegal usage of electric energy; it has received support from almost $90 \%$ of respondents.

The results of questionnaire items in factor E5 (the efficiency of management peculiarities and importance of security analysis) suggest that $80,4 \%$ of respondents agree that energy supply merchants should dismantle networks at objects where services are no longer provided (disused objects), thus preventing offenders from stealing electric energy and cables, and $79,2 \%$ of respondents agree that energy supply merchant should continue reconstruction of overhead lines into cable lines.

With respect to the indicators of factor E6 (the topicality of other possible propositions), about the necessity to recruit detectives by energy supply merchants, only $13,6 \%$ of respondents showed support, but the necessity to include in police inspection routes in those places where criminal offences are committed regularly is supported by $51,7 \%$ of respondents. These results indicate that the aforementioned proposals are not topical.

Significant correlation was established between the factors that reflect the evaluation of the problem and factors that reflect the efficiency of various groups of measures used to solve the problem (Table 5). For example, correlation between factors F3 and E4 has reflexive character $(\mathrm{r}=-0,230)$, which means that the higher respondents evaluate the level of judicial competence of the society, the lower they evaluate the efficiency of preventive measures and improvement of legislative framework. Such correlation was established also between factors F2 and E1 $(r=-0,466)$; that is, the higher respondents evaluate the level of resource provision, the less effective they believe those measures are that are related to correct information and public communication. Direct correlation was established between factors F1 and E1 $(\mathrm{r}=0,553)$ - the higher respondents evaluate the level of problem significance, the more 
effective they believe those measures are that are related to correct information and public communication. Correlation between factors F1 and E3 was also direct $(\mathrm{r}=0,584)$ - the higher respondents evaluate the level of problem significance, the more effective they believe those measures are that are related to the provision with modern technical aids. In the same way, direct correlation was established between factors F4 and E4 $(r=0,349)$ - the higher respondents evaluate the level of the impact of objective factors on the problem, the more effective they believe those measures are that are related to the efficiency of preventive measures and improvement of legislative framework.

Table 5. Correlation coefficient of factors which reflect the problem and factors which reflect the efficiency of various groups of measures used to solve the problem

\begin{tabular}{llllllll}
\hline Workplace & & $\mathrm{E} 1$ & $\mathrm{E} 2$ & $\mathrm{E} 3$ & $\mathrm{E} 4$ & $\mathrm{E} 5$ & $\mathrm{E} 6$ \\
\hline \multirow{4}{*}{$\begin{array}{l}\text { Law } \\
\text { enforcement }\end{array}$} & $\mathrm{F} 1$ &, $797^{* *}$ &, $403^{* *}$ &, $718^{* *}$ &, $602^{* *}$ &, 184 &,$- 277^{* *}$ \\
\cline { 2 - 7 } institution & $\mathrm{F} 2$ &,- 136 &,$- 237^{*}$ &,- 129 &,- 085 &,- 155 &,- 003 \\
\cline { 2 - 8 } & $\mathrm{F} 3$ &,- 155 &,$- 289^{* *}$ &,- 062 &,- 171 &,- 041 &,- 040 \\
\cline { 2 - 8 } & $\mathrm{F} 4$ &, $676^{* *}$ &, $336^{* *}$ &, $618^{* *}$ &, $423^{* *}$ &, $258^{* *}$ &,- 123 \\
\cline { 2 - 8 } & $\mathrm{F} 5$ &,$- 348^{* *}$ &, 132 &,$- 377^{* *}$ &,- 123 &, $229^{*}$ &, 185 \\
\hline \multirow{4}{*}{$\begin{array}{l}\text { Energy supply } \\
\text { company }\end{array}$} & $\mathrm{F} 1$ &, $354^{* *}$ &, $347^{* *}$ &, $445^{* *}$ &, $403^{* *}$ &, $276^{* *}$ &, 084 \\
\cline { 2 - 8 } & $\mathrm{F} 2$ &,$- 452^{* *}$ &,- 126 &,$- 180^{* *}$ &,- 136 &,- 059 &, 071 \\
\cline { 2 - 8 } & $\mathrm{F} 3$ &,- 107 &,$- 185^{* *}$ &,- 081 &,$- 260^{* *}$ &,- 100 &,- 054 \\
\cline { 2 - 8 } & $\mathrm{F} 4$ &, $378^{* *}$ &, 123 &, $190^{* *}$ &, $266^{* *}$ &,- 010 &,- 078 \\
\cline { 2 - 8 } & $\mathrm{F} 5$ &,$- 275^{* *}$ &, 049 &,- 117 &,- 033 &, 070 &, $287^{* *}$ \\
\hline
\end{tabular}

** Correlation is significant at the 0.01 level (2-tailed).

* Correlation is significant at the 0.05 level (2-tailed).

Source: own research.

The analysis of correlation between the factors that reflect evaluation of the problem and factors that reflect the efficiency of the solutions for the problem, according to police officers and employees of energy supply companies, identifies the following patterns:

- Correlation character is not sensitive to respondent's workplace: direct correlations observed among police officers are also direct among employees of energy supply companies.

- Direct correlation was established between factors F1 and E1, F1 and E2, F1 and E3, $\mathrm{F} 1$ and $\mathrm{E} 4, \mathrm{~F} 4$ and $\mathrm{E} 1, \mathrm{~F} 4$ and $\mathrm{E} 3$, and F4 and E4. But stronger correlation was observed among police officers than employees of energy supply companies; that is, for police officers the coherence between the vision of the problem and the efficiency of various groups of measures to solve this problem are stronger than for employees of energy supply companies.

- Factor F2 significantly correlates only with factor E2 among police officers. It is a reflexive correlation, which means that the higher respondents evaluate the level of resource provision, the less effective they believe those measures are that are related to resource provision.

- Significant reflexive correlations were observed between factors F2 and E1, and F2 and E3, among employees of energy supply companies; that is, the higher respondents evaluate the level of resource provision, the less effective they believe those measures are that are related to correct information and public communication, as well as modern technical aids.

- Significant direct correlations were observed between factors F4 and E2, and F4 and E5, among police officers, but among employees of energy supply companies these correlations are not statistically significant. 


\section{Conclusions}

The overall assessment of the questionnaire results confirmed the hypotheses, and the following conclusions were drawn:

1) With respect to the importance of the evaluation of criminal offences in the electric energy market, it was established that:

1.1. There are regular differences in respondents' opinions about the importance of the evaluation of criminal offences in the electric energy market, as specialists of law enforcement institutions evaluate higher the importance of damage as well as the relation of criminal offences in electric energy market to economic situations. They also believe that they do not have serious motivation to accomplish effective tasks to improve the situation. On the other hand, specialists of energy supply companies evaluate higher the danger of criminal offences, security, and the situation when the personnel of energy supply companies does not have serious motivation and is not interested to accomplish effective tasks to improve the situation. However, the evaluation of $92,8 \%$ of respondents suggests that criminal offences significantly damage not only energy supply merchants, but also public economy.

1.2. Security and protection of electric energy markets through criminal law is important and topical both for energy supply companies and law enforcement institutions.

1.3. There is a necessity for the improvement of legislative framework in order to prevent crimes and criminal offences in the electric energy market.

2) The analysis of the efficiency of the solutions for criminal offences in electric energy market established that:

2.1. Respondents gave the highest evaluation to the factor about the importance of technical aids provision; however, other factors, mentioned above, also received high evaluation.

2.2. There is interdependence between respondents' opinions about the evaluation of illegal usage of electric energy and the evaluation of the efficiency of various groups of measures to solve that problem. It was established that criminal liability should be applied after warning to the offenders of regular unauthorized connections to electric lines.

2.3. Police needs additional resource provision to carry out effective preventive measures, establish and summarize the determinants of criminal offences, and reduce and prevent their impact.

2.4. There is a necessity to motivate the employees of law enforcement institutions and energy supply merchants to disclose criminal offences in electric energy markets and to rouse their interest to accomplish effective tasks to improve the situation.

2.5. Energy supply merchants should provide police with operational data and correct information on criminal offences in electric energy markets, as well as close cooperation with police on the peculiarities of criminal offences in electric energy markets. It is necessary to provide opportunities for their disclosure and prevention.

3) In order to reduce criminal offences in electric energy markets, the energy supply merchant should:

3.1. Provide not only theoretical, but also practical training for the personnel, analyse criminal offences and set tactical goals, and control the application of knowledge in practice.

3.2. Before testing clients' objects, it is necessary to publish information in mass media on the complex of measures taken to detect cases of illegal usage of electric energy.

3.3. Install control measurement devices at distribution points.

3.4. Transfer measuring devices out of clients' territory.

3.5. Continue the program on replacement of current meters with smart meters that are able to provide information on the actual electric energy consumption.

3.6. Continue reconstruction of overhead lines into cable lines. 


\section{INTERDISCIPLINARY APPROACH TO ECONOMICS AND SOCIOLOGY}

3.7. Dismantle networks at objects where services are no longer provided (disused objects), thus preventing offenders from stealing electric energy and cables.

\section{References}

Balitskiy, S., Bilan, Y., Strielkowski, W. (2014), Energy security and economic growth in the European Union, Journal of Security and Sustainability Issues 4(2), pp. 123-130, http://dx.doi.org/10.9770/jssi.2014.4.2(2).

Balitskiy, S., Bilan, Y., Strielkowski, W., \& Streimikienè, D. (2016), Energy efficiency and natural gas consumption in the context of economic development in the European Union, Renewable and Sustainable Energy Reviews, Vol. 55, pp. 156-168, DOI: http://dx.doi.org/10.1016/j.rser.2015.10.053.

Balkyte, A., Tvaronavičiene, M. (2010), Perception of competitiveness in the context of sustainable development: facets of "sustainable competitiveness, Journal of Business Economics and Management 11(2), pp. 341-365.

Białowas, P. (2015), The models of business organization in the light of the privatization process on the example of Polish electricity sector, Journal of International Studies, Vol. 7, No. 3, pp. 234-243, DOI: http://dx.doi.org/10.14254/2071-8330.2015/8-3/19.

Bistrova, J., Lace, N., Tvaronavičienè, M. (2014), Corporate governance as a crucial factor in achieving sustainable corporate performance, Journal of systemics, cybernetics and informatics 12(3), pp. 82-90.

Branten, E., Purju, A. (2015), Cooperation projects between university and companies: process of formation and objectives of the stakeholders, Entrepreneurship and Sustainability Issues 3(2), pp. 149-156, http://dx.doi.org/10.9770/jesi.2015.3.2(3).

Byuyul, A., Tsyofel, P. (2005), SPSS: Iskusstvo obrabotki informatsii. Analiz statisticheskih dannyih $i$ vosstanovlenie skryityih zakonomernostey (Art of information procesing. Analysis of statistical data and revealing hidden consistent patterns), SPb: DiaSoftYuP, pp. 220-232, pp. 368-382.

Cherp, A., Jewell, J. (2014), The concept of energy security: Beyond the four As, Energy Policy 75, pp. 415-421.

Corneliu, M., Tamošiūnienè, R. (2015), Modern approaches in quantifying economic security. case sudy of Estonia, Latvia, Lithuania and Republic of Moldova, Journal of Security and Sustainability Issues 4(4), pp. 596-610, http://dx.doi.org/10.9770/jssi.2015.4.4(2)S.

Cuneo, A., Ferrari, M., Traverso, A., Massardo, A. (2014), Sustainable district development: a case of thermoeconomic optimization of an energy hub, Entrepreneurship and Sustainability Issues 2(2), pp. 74-85, http://dx.doi.org/10.9770/jesi.2014.2.2(3).

Čirjevskis, A. (2015), Dynamic capabilities in abmidextrous organisation, decision making pattern for sustainable future, Entrepreneurship and Sustainability Issues 3(2), pp. 129136, http://dx.doi.org/10.9770/jesi.2015.3.2(1).

Dezellus, E., Ferreira, L., Pereira, N., Vasiliūnaite, R. (2015), Entrepreneurship conditions: energy resources' Prices and energy consumprion peculiarities in developed countries, Entrepreneurship and Sustainability Issues 2(3), pp. 163-170, http://dx.doi.org/10.9770/jesi.2014.2.3(5).

Dudzevičiūtè, G., Mačiulis, A., Tvaronavičienė, M. (2014), Structural changes of economies: Lithuania in the global context, Technological and economic development of economy 20(2), pp. 353-370.

Dzemyda, I., Raudeliūnienè, J. (2014), Sustainable youth entrepreneurship in conditions of global economy toward energy security, Entrepreneurship and Sustainability Issues 1(4), pp. 247-256, http://dx.doi.org/10.9770/jesi.2014.1.4(7). 
Energéetikas attīstības pamatnostādnes 2016.-2020. gadam (Energy development guidelines for 2016-2020), Available on the Internet: < https://www.em.gov.lv/lv/jaunumi/8391mk-apstiprina-energetikas-attistibas-pamatnostadnes-2016-2020-gadam.>

Espona, R. J. de (2016), Energy Security, resilience and Critical InfrastructureProtection: Spanish Puertollano Refinery crisis case, Journal of Security and Sustainability Issues 5 (3), pp. 323-328, DoiI: http://dx.doi.org/10.9770/jssi.2016.5.3(2)

Fuschi, D., Tvaronavičienè, M. (2016), A network based business partnership model for SMEs management, Entrepreneurship and Sustainability Issues 3(3), pp. 282-289, http://dx.doi.org/10.9770/jesi.2016.3.3(5).

Garškaitè-Milvydienè, K. (2014), Anti-crisis management of enterprises as precondition of sustainable entrepreneurship, Entrepreneurship and Sustainability Issues 1(4), pp. 187203, http://dx.doi.org/10.9770/jesi.2014.1.4(1).

Gerlitz, L. (2016), Design management as a domain of smart and sustainable enterprise: business modelling for innovation and smart growth in Industry 4.0, Entrepreneurship and Sustainability Issues 3(3), pp. 244-268, http://dx.doi.org/10.9770/jesi.2016.3.3(3).

Giriūnienè, G. (2013), Public sector's subsidies to business - suitability valuation of labor market support measures, Entrepreneurship and Sustainability Issues 1(1), pp. 37-44, http://dx.doi.org/10.9770/jesi.2013.1.1(4).

Girūnas, L., Mackevičius, J. (2014), Evaluation of frauds in public sector, Entrepreneurship and Sustainability Issues 1(3), pp. 143-150, http://dx.doi.org/10.9770/jesi.2014.1.3(3).

Grubicka, J., Matuska, E. (2015), Sustainable entrepreneurship in conditions of UN (Safety) and technological convergence, Entrepreneurship and Sustainability Issues 2(4), pp. 188-197, http://dx.doi.org/10.9770/jesi.2015.2.4(2).

Guruz, R., Scherer, R. (2014), Sustainable energy entrepreneurship through architectural design: a key point controlled method, Entrepreneurship and Sustainability Issues 2(2), pp. 60-73, http://dx.doi.org/10.9770/jesi.2014.2.2(2).

Ignatavičius, R., Tvaronavičienè, M., Piccinetti, L. (2015), Sustainable development through technology transfer networks: case of Lithuania, Journal of Security and Sustainability Issues 4(3), pp. 261-267, http://dx.doi.org/10.9770/jssi.2015.4.3(6).

Išoraite, M. (2013), Motivation tools though lenses of prospective employees, Entrepreneurship and Sustainability Issues 1(2), pp. 116-123, http://dx.doi.org/10.9770/jesi.2013.1.2(6).

Jefremov, V., Rubanovskis, A. (2015), Towards a sustainable Latvian energy resources and energy markets in the context of the EU, Journal of Securityand Sustainability Issues 4(3), pp. 552-563, http://dx.doi.org/10.9770/jssi.2015.4.3(5)S.

Kryishtanovskiy, A. (2006), Analiz sotsiologicheskih dannyih s pomoschyu paketa SPSS (Analysis of sociological data by using SPSS package), M.: Izd. dom GU-VShE, pp. 192-206.

Lace, N., Buldakova, N., Rumbinaite, G. (2015), Organizational creativity as a driving force for company's innovative development, Entrepreneurship and Sustainability Issues 3(2), pp. 137-148, http://dx.doi.org/10.9770/jesi.2015.3.2(2).

Lapinskienė, G., Tvaronavičienè, M., Vaitkus, P. (2014), Greenhouse gases emissions and economic growth - evidence substantiating the presence of environmental Kuznets curve in the EU, Technological and Economic Development of Economy 20(1), pp. 65-78.

Lapinskienè, G., Tvaronavičienè, M., Vaitkus, P. (2013). The analysis of the validity of environmental Kuznets Curve for the Baltic States, Environmental and Climate Technologies 12, pp. 41-46.

Laužikas, M., Mokšeckienè, R. (2013), The role of creativity in sustainable business, Entrepreneurship and Sustainability Issues 1(1), pp. 10-22, http://dx.doi.org/10.9770/jesi.2013.1(2). 
Laužikas, M., Tindale, H., Bilota, A., Bielousovaitè, D. (2015), Contributions of sustainable start-up ecosystem to dynamics of start-up companies: the case of Lithuania, Entrepreneurship and Sustainability Issues 3(1), pp. 8-24, http://dx.doi.org/10.9770/jesi.2015.3.1(1).

Leonavičius, V., Genys, D., Krikštolaitis, R. (2015), Public perception of energy security in Lithuania, Journal of Security and Sustainability Issues 4(4), pp. 311-322, http://dx.doi.org/10.9770/jssi.2015.4.4(1).

Lisin, E., Rogalev, A., Strielkowski, W., Komarov, I. (2015), Sustainable Modernization of the Russian Power Utilities Industry, Sustainability, Vol. 7, pp. 11378-11400, DOI: http://dx.doi.org/10.3390/su70911378.

Månsson, A., Johansson, B., Nilsson, L. J. (2014), Assessing energy security: An overview of commonly used methodologies, Energy 73, pp. 1-14.

Miškinis, V., Baublys, J., Lekavičius, V., Morkvėnas, A. (2013), New Changes in Lithuanian Energy Sector, Journal of Security and Sustainability Issues 2(3), pp. 15-28, http://dx.doi.org/10.9770/jssi.2013.2.3(2).

Narula, K., Reddy, B. S. (2015), Three blind men and an elephant: The case of energy indices to measure energy security and energy sustainability, Energy 80, pp. 148-158.

Nasledov, A. (2005), SPSS - Kompyuternyiy analiz dannyih v psihologii i sotsialnyih naukah (Computer analysis of data in psychological and social sciences), Piter: SPb, pp. 280297.

Pires Manso, J. R., Fernandes de Matos, A. J., Carvalho, C. C. M. (2015), Determinants of Regional Growth in Portugal: An Empirical Analysis, Economics and Sociology, Vol. 8, No. 4, pp. 11-31, DOI: http://dx.doi.org/10.14254/2071-789X.2015/8-4/1.

Prause, G. (2016), E-Residency: a business platform for Industry 4.0? Entrepreneurship and Sustainability Issues 3(3), pp. 216-227, http://dx.doi.org/10.9770/jesi.2016.3.3(1).

Raudeliūnienè, J., Tvaronavičienè, M., Dzemyda, I., Sepehri, M. (2014), Sustainable entrepreneurship through energy stewardship: role of values and behavioral patterns, Entrepreneurship and Sustainability Issues 2(2), pp. 107-117, http://dx.doi.org/10.9770/jesi.2014.2.2(6).

Rezk, M., Ibrahim, H., Tvaronavičienė, M., Sakr, M., Piccinetti, L. (2015), Measuring innovations in Egypt: case of industry, Entrepreneurship and Sustainability Issues 3(1), pp. 47-55, http://dx.doi.org/10.9770/jesi.2015.3.1(4).

Ruza, A., Ruza, I., Rascevskis, V., Vorobjovs, A., Murasovs, V. (2016), Safety and security in the EU: Perception of Latvian residents, Journal of Security and Sustainability Issues 5(5), pp. 365-376.

The Directive 2009/72/EC of the European Parliament and of the Council of 13 July 2009 concerning common rules for the internal market in electricity and repealing Directive 2003/54/EC (Text with EEA relevance), available on the Internet: <http://eurlex.europa.eu/legal-content/EN/TXT/?uri=CELEX:32009L0072\&qid=1455452588612>

Tvaronavičienė, M., Mačiulis, A., Lankauskienė, T., Raudeliūnienė, J., Dzemyda, I. (2015), Energy security and sustainable competitiveness of industry development, Economic Research-Ekonomska Istraživanja 28(1), pp. 502-516.

Yadov, V. (2007), Strategiya sotsiologicheskogo issledovaniya (Strategy of sociological research), Moskva: Omega-L, pp. 219-223. 